\title{
First report of feline bocavirus associated with severe enteritis of cat in Northeast China, 2015
}

\author{
Chunguo LIU $^{1)}$, Fei LIU'2), Zhigang LI $^{4)}$, Liandong QU1)* and Dafei LIU1,3)* \\ 1) State Key Lab of Veterinary Biotechnology, Harbin Veterinary Research Institute, \\ Chinese Academy of Agricultural Sciences, Harbin, Heilongjiang 150069, China \\ ${ }^{2)}$ Shanghai Hile Bio-Pharmaceutical Co., Ltd., Shanghai, 201403, China \\ ${ }^{3)}$ College of Wildlife Resources, Northeast Forestry University, Harbin, Heilongjiang 150040, China \\ ${ }^{4)}$ Wendengying Veterinary Station, Weihai, Shandong 264413, China
}

\begin{abstract}
J. Vet. Med. Sci.
80(4): 731-735, 2018
\end{abstract}

doi: 10.1292/jvms.17-0444

Received: 10 August 2017

Accepted: 8 February 2018

Published online in J-STAGE:

20 February 2018
ABSTRACT. Feline bocavirus (FBoV) is a newly identified bocavirus of cats in the family Parvoviridae. A novel FBoV HRB2015-LDF was first identified from the cat with severe enteritis in Northeast China, with an overall positive rate of $2.78 \%$ (1/36). Phylogenetic and homologous analysis of the complete genome showed that FBoV HRB2015-LDF was clustered into the FBoV branch and closely related to other FBoVs, with 68.7-97.5\% identities. And the genes of VP1, NPA and NS1 shared 70.7-97.6, 72.4-98.6 and 67.2-98.0\% nucleotide identities with other FBoVs, respectively. The results suggested that the FBoVs could be divided into two distinct lineages, and the difference of nucleotide identities was $>20-30 \%$ between the lineages.

KEY WORDS: cat, China, enteritis, feline bocavirus (FBoV), genetic analysis

Bocavirus belongs to the genus Bocaparvovirus, subfamily Parvovirinae, family Parvoviridae, a small and non-enveloped virus approximately $25 \mathrm{~nm}$ in diameter [7], with a linear single strand DNA genome of approximately 5.4 kb [1, 6]. Bocavirus are unique among Parvoviridae as they contain a third ORF between the non-structural and structural-coding regions [11, 17, 23]. Previously, the genus Bocavirus was originally named according to the initial two members, bovine parvovirus (BPV) and minute virus of canines (MVC) [2, 19, 20, 28, 29]. And now, the genus of bocavirus is reclassified as Bocaparvovirus based on the proposal of Cotmore et al [7]. Currently, the bocaparvoviruses consist of carnivore bocaparvovirus, pinniped bocaparvovirus, primate bocaparvovirus, ungulate bocaparvovirus, and unclassified bocaparvovirus [20]. And the feline bocaviruses belong to carnivore bocaparvovirus 3 and unclassified bocaparvovirus, respectively [20].

Bocaparvoviruses frequently infect animals through the fecal-oral route, causing respiratory and gastrointestinal symptoms in young animals and humans [15], but are often subclinical in adults [3]. So far, bocaparvoviruses have identified from a variety of vertebrate hosts including humans [8], cows [4], pigs [5, 25, 26], gorillas [10], chimpanzees [27], California sea lions [16], dogs $[9,13,22,24]$, cats $[13,21,30,34]$, bats [33], rats [14], and pine martens [32], which suggested that the bocaparvoviruses have a very broad host range.

Feline bocavirus (FBoV) was first discovered in stray cats in Hong Kong [13]. And then the America and Portugal found the FBoVs were existed in the feces and brain of the cats [21, 34]. Commonly, the FBoV genome encodes three ORFs, ORF1, ORF2 and ORF3, which correspondingly encode non-structural protein NS1, overlapping capsid proteins VP1/VP2, and unique nonstructural nuclear phosphoprotein NP1, respectively [13, 21, 34]. While, there is no report about FBoV in mainland China. To investigate the infectious status of FBoV in Harbin of Heilongjiang province, fecal samples were collected from pet hospitals either with diarrheic or asymptomatic cats. This study was approved by the Harbin Veterinary Research Institute-Experimental Animal Welfare Ethics Committee (HVRI-EAWEC), and conducted under the guidance of the HVRI-EAWEC. The EAWEC approval number was SYXK (Hei) 2011-022.

Totally, in present study, 36 fecal samples of cats with diarrhea (13/36) or no clinical symptoms $(23 / 36)$ were randomly collected in Harbin city of Heilongjiang province from January 15 to February 28, 2015, and the samples was stored at $-80^{\circ} \mathrm{C}$. The detail information on the samples was listed in Table S1.

Viral gene sequencing and analysis were conducted as follows. In brief, Viral DNA was extracted directly from samples using the AxyPrep ${ }^{\text {TM }}$ Body Fluid Viral DNA/RNA Miniprep Kit (Axygen, Wujiang, China), according to the manufacturer's directions.

The identification of FBoV was performed using specific primers based on NS1 gene [13]. The primer sets are

*Correspondence to: Liu, D.: hattman324@hotmail.com, Qu, L.: quliandong@caas.cn

O2018 The Japanese Society of Veterinary Science

This is an open-access article distributed under the terms of the Creative Commons Attribution Non-Commercial No Derivatives (by-nc-nd) License. (CC-BY-NC-ND 4.0: https://creativecommons.org/licenses/by-nc-nd/4.o/) 
Table 1. The primers for amplification of full length genome of feline bocavirus

\begin{tabular}{ll}
\hline \multicolumn{1}{c}{ Primers } & \multicolumn{1}{c}{ Sequences } \\
\hline FBOV-21F & 5'-CTGCATTTCCGTGTCTGTGTCATT 3' \\
FBOV-1491R & 5'-GCATTCACGATTGCTTTTGCCAG-3' \\
FBOV-1307F & 5'-GCAGACTCRCTCCACGCTAAT-3' \\
FBOV-3256R & 5'-CGCGTTTTCCACCAGTTCCT-3' \\
FBOV-3149F & 5'-CCGGGTGGCTGGGAAAATC-3' \\
FBOV-5178R & 5'-CATGGGCGTAGCAGTGTGGA-3' \\
\hline
\end{tabular}

Table 2. The homologous comparison of the nucleotide sequence of feline bocavirus HRB2015-LDF and the bocaviruses derived from different hosts available in GenBank

\begin{tabular}{llcccc}
\hline \multirow{2}{*}{ Host } & \multirow{2}{*}{ Strain or Group } & \multicolumn{4}{c}{ HRB2015-LDF (\%) } \\
\cline { 3 - 6 } Cat & HK875F & Genome & VP1 & NP1 & NS1 \\
& HK797F & 97.5 & 97.2 & 98.0 & 97.8 \\
& HK797U & 97.0 & 96.2 & 98.3 & 97.3 \\
& FBD1 & 96.9 & 96.2 & 98.3 & 97.4 \\
& FBD2 & 74.9 & 75.3 & 77.2 & 74.3 \\
& POR1 & 97.0 & 96.3 & 98.4 & 97.5 \\
Rabbit & MG132 & 68.7 & 70.7 & 72.4 & 67.2 \\
Gorilla & gorilla/GBoV1/2009 & $-\mathrm{a})$ & - & 98.6 & 98.0 \\
Primate & CPZh2 & 50.9 & 52.7 & 52.6 & 45.0 \\
Bat & BtBoV group & 49.2 & 55.0 & 53.0 & 45.6 \\
Dog & CMV group & $45.2-59.9$ & $51.3-6-62.9$ & $34.6-59.4$ & $45.2-49.6$ \\
& CBoV group & $29.7-58.9$ & $60.5-63.3$ & $54.2-55.0$ & $54.1-54.5$ \\
Sea lion & CslBoV group & $27.6-38.2$ & $60.5-62.1$ & $55.6-56.8$ & $46.4-47.4$ \\
Human & HBoV group & $28.9-58.5$ & $52.1-53.1$ & $53.8-55.9$ & $51.9-52.0$ \\
Pig & PBoV group & $25.5-52.9$ & $30.5-46.9$ & $26.4-59.2$ & $26.9-50.2$ \\
\hline
\end{tabular}

CBoV: Canine bocavirus: CMV: Canine_minute_virus; PBoV: Porcine bocavirus; CslBoV: California sea lion bocavirus; HBoV: Human bocavirus; Bat bocavirus: $\mathrm{BtBoV}$. a) The dash represent that the sequence was not available in GenBank.

5'-GCCAGCACNGGNAARACMAA-3' (forward) and 5'-CATNAGNCAYTCYTCCCACCA-3' (reverse). The PCR product size is $141 \mathrm{bp}$. The amplification of full length genome of FBoV was conducted by using three pairs of specific primers of FBoV (Table 1). PCR products were purified with the QIA quick PCR purification Kit (Qiagen, Hilden, Germany) and cloned into pMD18-T vector (TaKaRa, Dalian, China), then sequenced using vector specific sequencing primers by Invitrogen Co.

Sequence data were edited by using SeqMan program and the homology was analyzed by using MegAlign program (DNASTAR, Madison, WI). The phylogenetic trees were generated with the soft of MEGA 7 [12] by using the Clustal W alignment algorithm and the maximum likelihood method, and bootstrap analysis was performed with 1,000 replicates.

Of 36 fecal samples of cats, one FBoV named as HRB2015-LDF strain was identified from a three-month-old male cat with severe enteritis, and with an overall positive rate of $2.78 \%$ (1/36). The genome of HRB2015-LDF strain, 5,125 nucleotides (nts) in length, contains three open reading frames (ORFs), which are 2,415 nts of NS1, 657 nts of NP1 and 2,139 nts of VP1/VP2 encoding three proteins of 804, 218 and 712 residues, respectively. The full length genome sequence of FBoV HRB2015-LDF was deposited in GenBank with the accession number of KX228695.

The amino acid sequence analysis of VP1, NP1 and NS1 proteins showed that the HRB2015-LDF had no deletion and insertion and kept the same pattern with the Hong Kong isolates and one American isolate FBD2, while the phenomenon of deletion and insertion frequently happened to another American isolate FBD1 and Portuguese isolate POR1 compared with the reference isolate of HK875F. And both these two isolates of FBD1 and POR1, they also had no same deletion and insertion pattern compared each other (Fig. S1).

To compare the homology, all the nucleotide sequences of bocaviruses derived from different hosts available in GenBank were downloaded and analyzed. The homology of complete genomic sequence of HRB2015-LDF closely related to other FBoVs, with $68.7-97.5 \%$ nucleotide identities, and distantly related to other host bocaviruses, with $\leq 63.3 \%$ nucleotide identities. Among the FBoVs, HRB2015-LDF was highly closed to all three Hong Kong isolates, and one America isolate FBD2, with $\geq 96.9 \%$ nucleotide identities, while, with $\leq 74.9 \%$ nucleotide identities to the American isolate FBD1 and Portuguese isolate POR1, and the homology of nucleotide sequence between FBD1 and POR1 was 68.2\% (Tables 2 and 3). The other genes of VP1, NP1 and 
Table 3. The comparison of nucleotide (amino acid) sequences of feline bocaviruses among caldes or between HRB2015-LDF and clades

\begin{tabular}{lccccccc}
\hline \multirow{2}{*}{ Gene } & \multicolumn{7}{c}{ Homology (\%) } \\
\cline { 2 - 8 } & Clade1 & Clade1-POR1 & Clade1-FBD1 & FBD1-POR1 & $\begin{array}{r}\text { HRB2015- } \\
\text { LDF-Clade1 }\end{array}$ & $\begin{array}{r}\text { HRB2015- } \\
\text { LDF-POR1 }\end{array}$ & $\begin{array}{c}\text { HRB2015- } \\
\text { LDF-FBD1 }\end{array}$ \\
\hline VP1 & $96.2-100.0$ & $70.7-71.1$ & $75.4-75.7$ & $69.9(70.0)$ & $\begin{array}{r}96.2-97.3 \\
(95.8-97.1)\end{array}$ & $70.7(70.8)$ & $75.6(78.2)$ \\
& $(95.8-100.0)$ & $(70.5-71.2)$ & $(77.6-78.3)$ & & 71.8 & \\
\hline NP1 & $98.0-100.0$ & $70.5-71.6$ & $76.8-77.4$ & $71.2(67.4)$ & $98.0-98.6$ & $71.4(63.1)$ & $77.1(71.4)$ \\
& $(96.5-100.0)$ & $(62.7-63.1)$ & $(70.9-71.8)$ & & $(97.0-98.7)$ & & \\
\hline NS1 & $97.3-99.8$ & $67.1-67.4$ & $74.3-74.6$ & $68.4(68.3)$ & $97.3-98.0$ & $67.2(67.3)$ & $74.3(75.7)$ \\
& $(97.3-99.6)$ & $(67.2-67.9)$ & $(75.7-76.1)$ & & $(97.4-98.3)$ & & \\
\hline Genome & $96.9-97.5$ & $68.2-68.8$ & $74.9-75.9$ & 68.2 & $96.9-97.5$ & 68.7 & 74.9 \\
\hline
\end{tabular}

NS1 of HRB2015-LDF showed the same homologous relationship, with 70.7-97.6, 72.4-98.6 and 67.2-98.0\% nucleotide identities to the corresponding genes of FBoVs, respectively. The homologous analysis of amino acid sequence showed the identities with the nucleotide sequence (Tables 2 and 3). The results of homologous analysis suggested that the FBoVs have evolved into three different lineages. The HRB2015-LDF, three Hong Kong isolates, and one America isolate FBD2 have the high similarity, which can be divided into a class named clade3. And there have great difference among FBD1, POR1, and clade1 (Table 3), so the POR1 and FBD1 were designated clade1 and clade2, respectively.

To characterize the genetic relationships of bocaviruses from different species, the phylogenetic trees of full genome and each gene of FBoV HRB2015-LDF were constructed with all the nucleotide sequence of bocaviruses available in GenBank. The phylogenetic tree of genome and each gene of HRB2015-LDF showed that HRB2015-LDF was clustered into the FBoV branch, and all FBoVs were co-located the same branch with the canine minute viruses. And in the FBoV branch, the HRB2015-LDF, three Hong Kong isolates, and one America isolate FBD2 closely clustered together, while the FBD1 and POR1 located the out branch (Figs. 1 and 2), which strongly supported the opinion that the FBoVs could be divided into three clades as mentioned above.

Cats are one of the most common and important companion animals, and humans keep more than 80 million cats worldwide [21]. Until now, though more than 15 viral families have now been described in cats, only known rabies virus and rotaviruses can infect humans [31]. Bocaviruses have been associated with diarrheal and respiratory illnesses in human and other mammals such as dogs, cattle, and pig, but for pathogenicity of bocaviruses derived from other hosts remains large unknown [18]. Of the 36 fecal samples, one positive sample was identified in diarrheal cat, and no other common and emerging viral diarrheal pathogens including DNA virus (feline parvovirus) and RNA viruses (feline coronavirus, feline calicivirus, feline astrovirus, feline kobuvirus, feline rotavirus, and feline norovirus, etc.) were found by PCR and virus isolation, which suggested that the FBoVs might be one of the important factors to cause the viral diarrhea in cats, or provide synergistic effects on diarrheic disease progression of cats with other pathogens that cause diarrhea. For that once was overlooked by us.

In present study, the first FBoV HRB2015-LDF was identified and characterized in diarrheal cat in mainland China, and the classification of FBoVs based on the homology and phylogeny was also put forward for consideration first time. However, the FBoVs remain too much unknown. Therefore, at present, extensively epidemiological and molecular survey need to be further study in China.

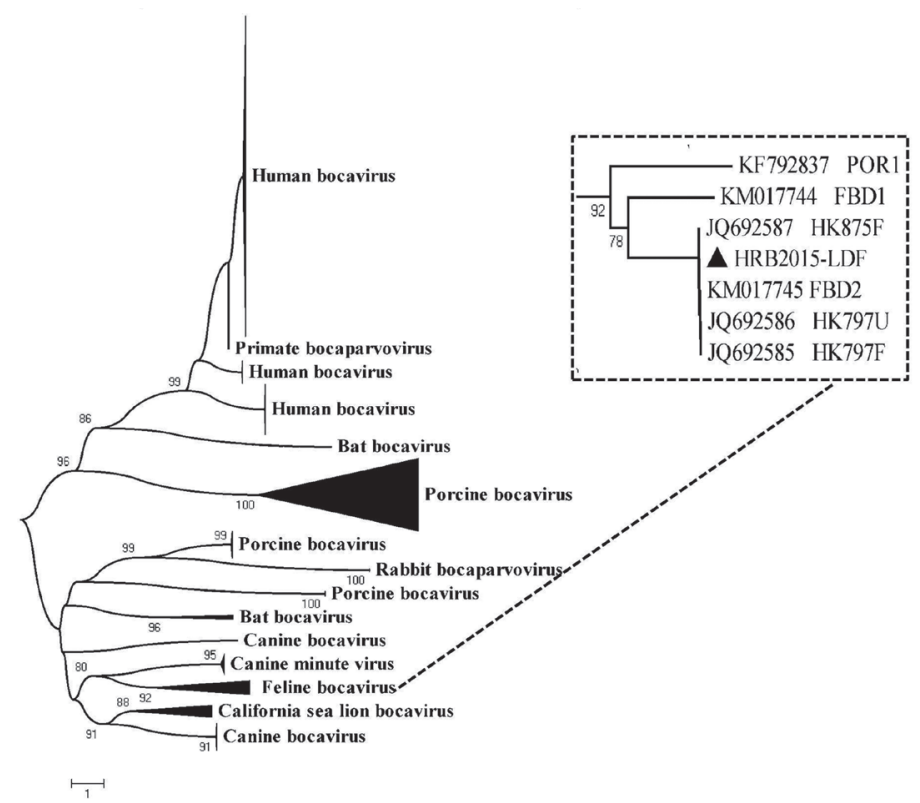

Fig. 1. Phylogenetic analysis of genome of feline bocaviruses. Phylogenetic tree of the full length genome derived different hosts available in GenBank and the feline bocavirus HRB2015-LDF identified in this study (marked with black triangle) was constructed using the neighborrjoining clustering method in MEGA version 7 with a p-distance. Bootstrap analysis was performed with 1,000 replicates and the bootstrap values for each node are given if $>70 \%$. Scale bar indicates nucleotide substitutions per site. 
A

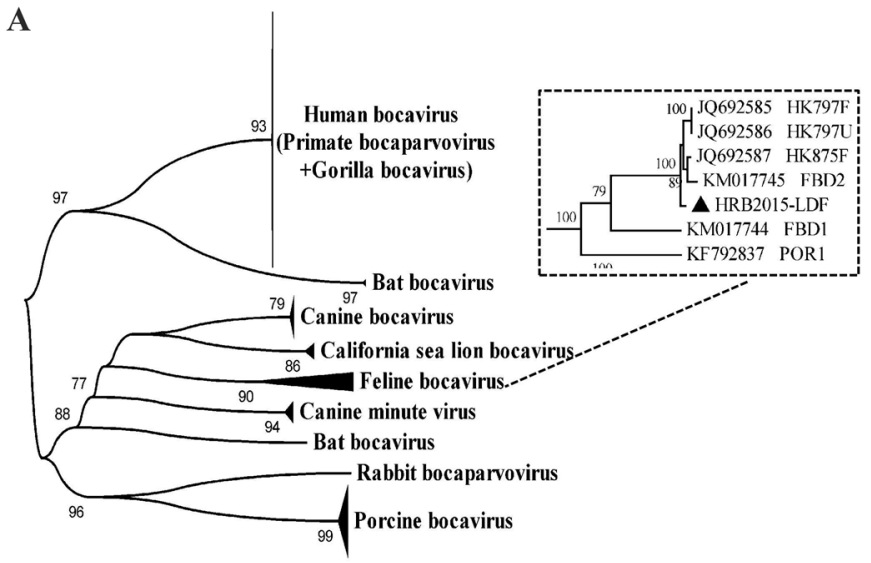

$\longmapsto$

C

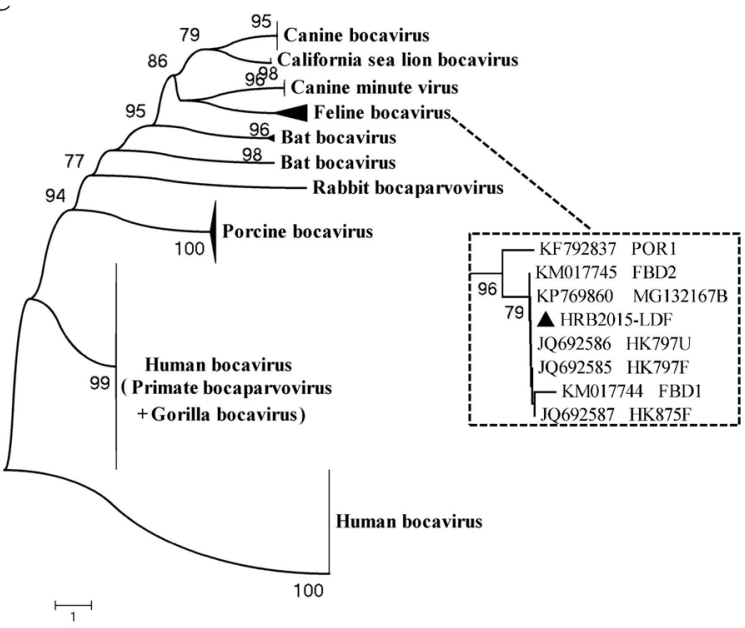

B

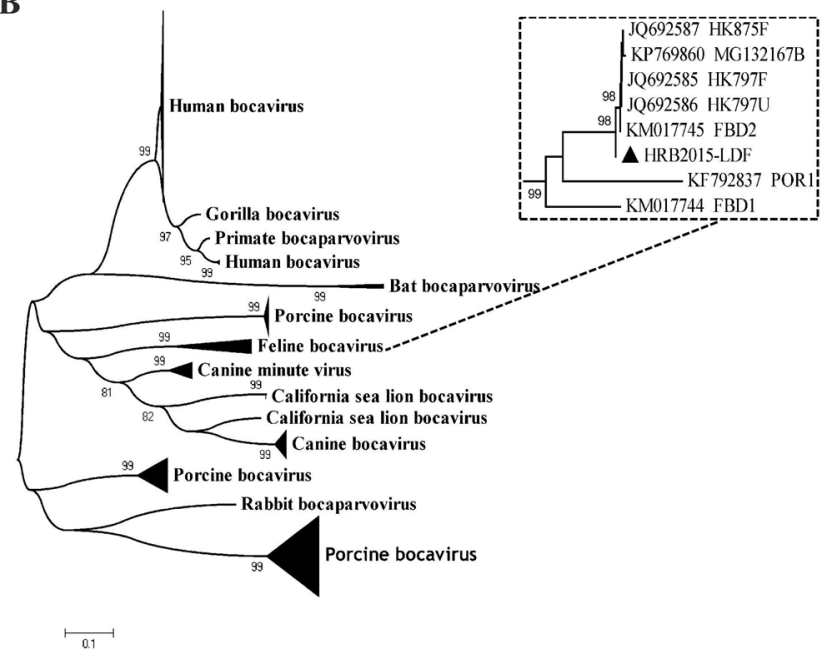

Fig. 2. Phylogenetic analysis of VP1, NP1 and NS1 genes of feline bocaviruses. Phylogenetic trees of the VP1 (A), NP1 (B) and NS1 (C) genes of the feline bocavirus HRB2015-LDF identified in this study (marked with black triangle) and the corresponding genes of bocaviruses derived different hosts available in GenBank were constructed using the neighbor-joining clustering method in MEGA version 7 with a p-distance. Bootstrap analysis was performed with 1,000 replicates and the bootstrap values for each node are given if $>70 \%$. Scale bar indicates nucleotide substitutions per site.

CONFLICT OF INTEREST. Authors have no conflict of interest to declare.

ACKNOWLEDGMENT. This work was supported by the Heilongjiang Postdoctoral Financial Assistance (LBH-Z13043), the China Postdoctoral Science Foundation Funded Project (2014M561320).

\section{REFERENCES}

1. Babkin, I. V., Tyumentsev, A. I., Tikunov, A. Y., Zhirakovskaia, E. V., Netesov, S. V. and Tikunova, N. V. 2015. A study of the human bocavirus replicative genome structures. Virus Res. 195: 196-202. [Medline] [CrossRef]

2. Binn, L. N., Lazar, E. C., Eddy, G. A. and Kajima, M. 1970. Recovery and characterization of a minute virus of canines. Infect. Immun. 1: 503-508. [Medline]

3. Carmichael, L. E., Schlafer, D. H. and Hashimoto, A. 1991. Pathogenicity of minute virus of canines (MVC) for the canine fetus. Cornell Vet. 81: 151-171. [Medline]

4. Chen, K. C., Shull, B. C., Moses, E. A., Lederman, M., Stout, E. R. and Bates, R. C. 1986. Complete nucleotide sequence and genome organization of bovine parvovirus. J. Virol. 60: 1085-1097. [Medline]

5. Cheng, W. X., Li, J. S., Huang, C. P., Yao, D. P., Liu, N., Cui, S. X., Jin, Y. and Duan, Z. J. 2010. Identification and nearly full-length genome characterization of novel porcine bocaviruses. PLoS ONE 5: e13583. [Medline] [CrossRef]

6. Choi, J. W., Lee, K. H., Lee, J. I., Lee, M. H., Lee, K. K. and Oem, J. K. 2015. Genetic characteristics of canine bocaviruses in Korean dogs. Vet. Microbiol. 179: 177-183. [Medline] [CrossRef] 
7. Cotmore, S. F., Agbandje-McKenna, M., Chiorini, J. A., Mukha, D. V., Pintel, D. J., Qiu, J., Soderlund-Venermo, M., Tattersall, P., Tijssen, P., Gatherer, D. and Davison, A. J. 2014. The family Parvoviridae. Arch. Virol. 159: 1239-1247. [Medline] [CrossRef]

8. Jartti, T., Hedman, K., Jartti, L., Ruuskanen, O., Allander, T. and Söderlund-Venermo, M. 2012. Human bocavirus-the first 5 years. Rev. Med. Virol. 22: 46-64. [Medline] [CrossRef]

9. Kapoor, A., Mehta, N., Dubovi, E. J., Simmonds, P., Govindasamy, L., Medina, J. L., Street, C., Shields, S. and Lipkin, W. I. 2012. Characterization of novel canine bocaviruses and their association with respiratory disease. J. Gen. Virol. 93: 341-346. [Medline] [CrossRef]

10. Kapoor, A., Mehta, N., Esper, F., Poljsak-Prijatelj, M., Quan, P. L., Qaisar, N., Delwart, E. and Lipkin, W. I. 2010. Identification and characterization of a new bocavirus species in gorillas. PLOS ONE 5: e11948. [Medline] [CrossRef]

11. Kapoor, A., Simmonds, P., Slikas, E., Li, L., Bodhidatta, L., Sethabutr, O., Triki, H., Bahri, O., Oderinde, B. S., Baba, M. M., Bukbuk, D. N., Besser, J., Bartkus, J. and Delwart, E. 2010. Human bocaviruses are highly diverse, dispersed, recombination prone, and prevalent in enteric infections. J. Infect. Dis. 201: 1633-1643. [Medline] [CrossRef]

12. Kumar, S., Stecher, G. and Tamura, K. 2016. MEGA7: molecular evolutionary genetics analysis version 70 for bigger datasets. Mol. Biol. Evol. 33 1870-1874. [Medline] [CrossRef]

13. Lau, S. K., Woo, P. C., Yeung, H. C., Teng, J. L., Wu, Y., Bai, R., Fan, R. Y., Chan, K. H. and Yuen, K. Y. 2012. Identification and characterization of bocaviruses in cats and dogs reveals a novel feline bocavirus and a novel genetic group of canine bocavirus. J. Gen. Virol. 93: $1573-1582$. [Medline] [CrossRef]

14. Lau, S. K., Yeung, H. C., Li, K. S., Lam, C. S., Cai, J. P., Yuen, M. C., Wang, M., Zheng, B. J., Woo, P. C. and Yuen, K. Y. 2017. Identification and genomic characterization of a novel rat bocavirus from brown rats in China. Infect. Genet. Evol. 47: 68-76. [Medline] [CrossRef]

15. Li, L., Pesavento, P. A., Leutenegger, C. M., Estrada, M., Coffey, L. L., Naccache, S. N., Samayoa, E., Chiu, C., Qiu, J., Wang, C., Deng, X. and Delwart, E. 2013. A novel bocavirus in canine liver. Virol. J. 10: 54. [Medline] [CrossRef]

16. Li, L., Shan, T., Wang, C., Côté, C., Kolman, J., Onions, D., Gulland, F. M. and Delwart, E. 2011. The fecal viral flora of California sea lions. J. Virol. 85: 9909-9917. [Medline] [CrossRef]

17. Manteufel, J. and Truyen, U. 2008. Animal bocaviruses: a brief review. Intervirology 51: 328-334. [Medline] [CrossRef]

18. Martin, E. T., Taylor, J., Kuypers, J., Magaret, A., Wald, A., Zerr, D. and Englund, J. A. 2009. Detection of bocavirus in saliva of children with and without respiratory illness. J. Clin. Microbiol. 47: 4131-4132. [Medline] [CrossRef]

19. Mochizuki, M., Hashimoto, M., Hajima, T., Takiguchi, M., Hashimoto, A., Une, Y., Roerink, F., Ohshima, T., Parrish, C. R. and Carmichael, L. E. 2002. Virologic and serologic identification of minute virus of canines (canine parvovirus type 1) from dogs in Japan. J. Clin. Microbiol. 40: 3993-3998. [Medline] [CrossRef]

20. National Center for Biotechnology Information Taxonomy/Browser. https://www.ncbi.nlm.nih.gov/Taxonomy/Browser/wwwtax.cgi?mode=Undef\& id $=1507401 \& l v l=3 \& \operatorname{lin}=$ s\&keep $=1 \&$ srchmode $=1 \&$ unlock\&log_op=lineage_toggle [accessed January 5, 2018].

21. Ng, T. F., Mesquita, J. R., Nascimento, M. S., Kondov, N. O., Wong, W., Reuter, G., Knowles, N. J., Vega, E., Esona, M. D., Deng, X., Vinjé, J. and Delwart, E. 2014. Feline fecal virome reveals novel and prevalent enteric viruses. Vet. Microbiol. 171: 102-111. [Medline] [CrossRef]

22. Ohshima, T., Kawakami, K., Abe, T. and Mochizuki, M. 2010. A minute virus of canines (MVC: canine bocavirus) isolated from an elderly dog with severe gastroenteritis, and phylogenetic analysis of MVC strains. Vet. Microbiol. 145: 334-338. [Medline] [CrossRef]

23. Qiu, J., Cheng, F., Johnson, F. B. and Pintel, D. 2007. The transcription profile of the bocavirus bovine parvovirus is unlike those of previously characterized parvoviruses. J. Virol. 81: 12080-12085. [Medline] [CrossRef]

24. Schwartz, D., Green, B., Carmichael, L. E. and Parrish, C. R. 2002. The canine minute virus (minute virus of canines) is a distinct parvovirus that is most similar to bovine parvovirus. Virology 302: 219-223. [Medline] [CrossRef]

25. Shan, T., Lan, D., Li, L., Wang, C., Cui, L., Zhang, W., Hua, X., Zhu, C., Zhao, W. and Delwart, E. 2011. Genomic characterization and high prevalence of bocaviruses in swine. PLoS ONE 6: e17292. [Medline] [CrossRef]

26. Shan, T., Li, L., Simmonds, P., Wang, C., Moeser, A. and Delwart, E. 2011. The fecal virome of pigs on a high-density farm. J. Virol. 85: 1169711708. [Medline] [CrossRef]

27. Sharp, C. P., LeBreton, M., Kantola, K., Nana, A., Diffo, J. D., Djoko, C. F., Tamoufe, U., Kiyang, J. A., Babila, T. G., Ngole, E. M., Pybus, O. G., Delwart, E., Delaporte, E., Peeters, M., Soderlund-Venermo, M., Hedman, K., Wolfe, N. D. and Simmonds, P. 2010. Widespread infection with homologues of human parvoviruses B19, PARV4, and human bocavirus of chimpanzees and gorillas in the wild. J. Virol. 84: 10289-10296. [Medline] [CrossRef]

28. Spahn, G. J., Mohanty, S. B. and Hetrick, F. M. 1966. Experimental infection of calves with hemadsorbing enteric (HADEN) virus. Cornell Vet. 56: 377-386. [Medline]

29. Storz, J., Leary, J. J., Carlson, J. H. and Bates, R. C. 1978. Parvoviruses associated with diarrhea in calves. J. Am. Vet. Med. Assoc. 173: 624-627. [Medline]

30. Takano, T., Takadate, Y., Doki, T. and Hohdatsu, T. 2016. Genetic characterization of feline bocavirus detected in cats in Japan. Arch. Virol. 161: 2825-2828. [Medline] [CrossRef]

31. Tsugawa, T. and Hoshino, Y. 2008. Whole genome sequence and phylogenetic analyses reveal human rotavirus G3P[3] strains Ro1845 and HCR3A are examples of direct virion transmission of canine/feline rotaviruses to humans. Virology 380: 344-353. [Medline] [CrossRef]

32. van den Brand, J. M., van Leeuwen, M., Schapendonk, C. M., Simon, J. H., Haagmans, B. L., Osterhaus, A. D. and Smits, S. L. 2012. Metagenomic analysis of the viral flora of pine marten and European badger feces. J. Virol. 86: 2360-2365. [Medline] [CrossRef]

33. Wu, Z., Ren, X., Yang, L., Hu, Y., Yang, J., He, G., Zhang, J., Dong, J., Sun, L., Du, J., Liu, L., Xue, Y., Wang, J., Yang, F., Zhang, S. and Jin, Q. 2012. Virome analysis for identification of novel mammalian viruses in bat species from Chinese provinces. J. Virol. 86: 10999-11012. [Medline] [CrossRef]

34. Zhang, W., Li, L., Deng, X., Kapusinszky, B., Pesavento, P. A. and Delwart, E. 2014. Faecal virome of cats in an animal shelter. J. Gen. Virol. 95: 2553-2564. [Medline] [CrossRef] 